\title{
有機金属化合物の反応性亡 $\boldsymbol{\sigma}-\boldsymbol{\pi}$ 共役
}

\author{
細見 \\ $\sigma-\pi$ Conjugation Governing Chemical Reactivities of Organometallic \\ Compounds
}

彰*

Akira Hosomi*

The electron deficient center (carbonium ions or other cations) at the $\beta$-position from a metal in organometallic compounds is stabilized by a hyperconjugation ( $\sigma-\pi$ conjugation) which has shown a very large resonance effect. Such a conjugative delocalization of neighboring $\sigma$ bonds is available without changing the reactant geometry and is termed "vertical stabilization". Furthermore this is completely separated from the electron-donating inductive effect by means of the demonstration of stereo electronic requirements. The effects of structural changes on the magnitude of the vertical $\sigma-\pi$ conjugation are also discussed in details.

\section{1.はじめに}

有機金属化合物は種々の興味㐫る反応性を示すが，な かでも，金属の $\beta$-位に炭素陽イオンやラジカル中心が 生成するような反応の速度が非常に大きいことは注目に 值する。カルボニウムイオンのときにはオレフィンの脱 離を伴うことが多い。この速い反応は遷移金属化合物で は安定なオレフィン錯体を形成する場合に多くみられる ため, オレフィン錯体形成による安定化に帰せられてき た が，この効果はケイ素，ゲルマニウム，スズなどの 安定なオレフィン $\pi$ 錯体を作りえない典型金属化合物で も観察され2)，有機金属化合物一般の現象であることが わかる。

近年これら効果を少し整理した形で理解しようとする 試みがなされ，かなりの成功を収めている。ここでは有 機金属化合物の $\beta$-位の反応性を支配する因子としての $\sigma-\pi$ 共役について, 主として有機化学的手法を用いた例 証をあげながら考察してみようと思う ${ }^{2 a)}$ 。理論的な取扱 いについては最近の Pitt による解説 ${ }^{3)}$, Hoffmann ら の論文 ${ }^{4)}$, 吉 良, 桜井の総説 ${ }^{5)}$ を参照されたい。摂動分 子軌道法は取扱いが簡単であり, これら共役効果に対す

* 東北大学理学部化学科

* Department of Chemistry, Faculty of Science, Tohoku University
る理解を深めるのに役立つ。

\section{2. $\sigma-\pi$ 共役}

ブタジエンやアクロレインのよらな隣接する $\pi$ 結合で は， $\pi$ 電子が分子全体にわたって非局在化することが知 られている ${ }^{6 \sim 8)}$ が，単に $\sigma$ 結合が $\pi$ 結合に隣接する化合 物でも同様の非局在化現象が見出された。前者は“共 役”といわれ，後者は特に “超共役”と呼ばれた ${ }^{2 \mathrm{~b})}$ 。最 近では $\pi$ 結合と共役する電子の名を冠せて名づけられて

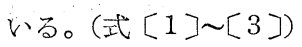

$\pi-\pi$ 共役

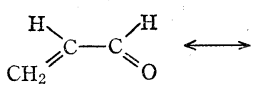<smiles>[1H]C([O-])=C[CH2+]</smiles>

$n-\pi$ 共役

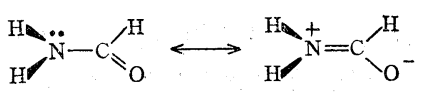

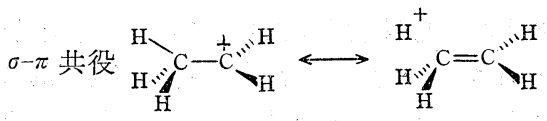

量子化学的に取扱った Mulliken による C-H 超共役 の考察に端を発したこれら研究は, その後種々の化学反 応性, あるいは物理的性質を説明する一つの概念を確立 してきた。 $\sigma-\pi$ 共役が寄与すると考えられるいくつかの 例をあげよう。 
1) プロピレンでは $\mathrm{CH}_{3}-\mathrm{C} \sigma$ 結合距離が短い ${ }^{7,9)}$ 。<smiles>C#CCCC=C=C</smiles>

2）シクロプロピルカルビニル系，あるいは同様に歪 みのある $\sigma$ 結合をもつ化合物（ハロゲン化合物，トシラ 一トなど）でみられる非常に速い加溶媒分解速度（カル ボニウムイオン生成) ${ }^{10)}$

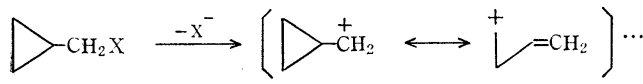

3） ベンジルハライドの加溶媒分解で， $t$-ブチル基よ りメチル基がカルボニウムイオン生成に対して加速効果 を示す ${ }^{6)}$ 。

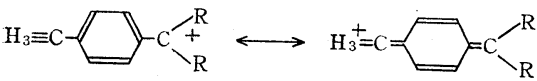

4）二級ラジカルよりも三級ラジカルの方が生成しや すく安定である ${ }^{11) 。 ~}$

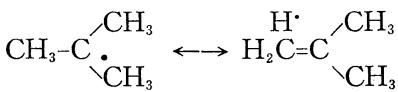

しかしながら，これら現象はいずれも別の概念による説

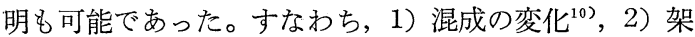
橋 ${ }^{12)}$ もくは環開裂 ${ }^{13)}$ にる安定化，3）溶媒和効果 ${ }^{14)}$, 4) 誘起 $(+I)$ 効果 ${ }^{15,16)}$ もしは $\beta$-歪み効果 ${ }^{17)}$ である。

一方，有機金属化合:物である $\alpha$-メタロアルキルケト ンではカルボニル波数が低くなることが知られている ${ }^{18}$, 19)。これは下に示すような金属一炭素 $\sigma$ 結合が $\pi$ 結合と 共役する $\sigma-\pi$ 共役によって説明されるが，一方，I 効 果や ${ }^{15.16)}$ 金属 $d$ 軌道関与によるとする説明もまた可能

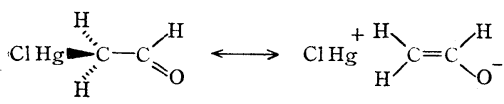

であろう。

このような化学的, 物理的性質に対する説明の相違点 を解消し，より統一的な考え方をまとめ，それを証明す るにはどのような手段をとればよいか。古く，有機金属 化合物の反応性などを説明するために提案された金属一 炭素 $\sigma$ 軌道の関与 $\left(\sigma-\pi\right.$ 共役) は $^{8,20)}$, 金 属が電気的に 陽性な元素であるために $+I$ 効果と混同され ${ }^{15,16)}$ ，そ れに反応性における加速効果や物理的性質の相異の全て を押し込められて，長い間日の目をみなかったが，最近 の Traylor を中心とする研究グループの積極的な研究 ${ }^{21)}$ の結果， $\sigma-\pi$ 共役の重要性が再び指摘され，その存在の 確立の実験, 証明がされるに至って以来, 脚光を浴びる ようになった。
このような $\sigma-\pi$ 共役を研究する上で最も適した系は, Winstein らによるホモ芳香族性の研究 ${ }^{22}$ でも明らかな ように, シクロプロパンのような歪みの大きい炭素-炭 素 $\sigma$ 結合を含む化合物であり，また，Traylor らが主と して研究した金属一炭素 $\sigma$ 結合のように分極した（polarized） $\sigma$ 結合をもつ化合物で，しかも電子欠乏中心であ るカチオン生成反応であり，これらの系では大きい安定 化が期待される。これらは “高揚された (exalted)” $\sigma-\pi$ 共役によってその効果が増幅され, 検出も容易で, 直接 証明のよいモデルを提供するであろう。通常 C-C や $\mathrm{C}-\mathrm{H}$ 超共役よりも数 $\mathrm{kcal} / \mathrm{mol}$ も隣接カルボウムイオ ンの安定化をもたらす。ただ， $\sigma-\pi$ 共役は “共役”が意 味するように悠密には電子の非局在化の過程において共 役に関与する $\sigma$ 結合や $\pi$ 系において結合角や結合距離の 変化を伴わない“垂直 (vertical) 安定化”を意味するの で，これをテストするためには垂直な過程の反応を選ん でやる必要がある。

\section{3. カルボニウムイオン安定化の様式}

カルボニウムイオンを中間体として経由する，あるい はカルボニウムイオンの遷移状態を通る反応で，その速 度を促進する効果として隣接基関与がある。たとえば， 酸素，硫黄，八ロゲンのような孤立電子対を含む隣接基 は求核基として働き，古典的な分子内 $\mathrm{S}_{\mathrm{N}} 2$ 型置換によ り生成するカルボニウムイオンに近づき，部分的に $\sigma$ 結 合を形づくり安定化しうるため, 加速効果がみられるこ とはよく知られた事実である。

これを NDI (Internal Nucleophilic Displacement) による安定化とする。構造 $(\mathrm{A})^{21 \mathrm{a}, \mathrm{c})}$ に示される。
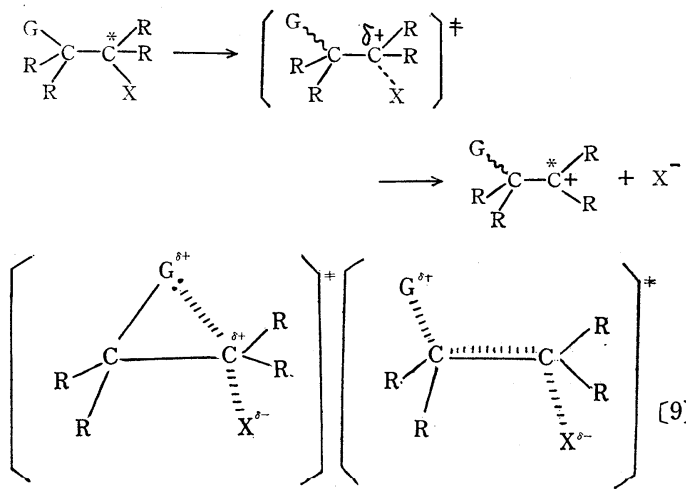

(A)

(B)

一方, 電子供与性共役効果 ( $+R$ 効果) による安定化 としては，当然カルボニウムイオンに直接結合した $\pi$ 電 子をもつフェニル基，ビニル基や， $n$ 電子をもつ酸素, 
窒素などの孤立電子対が直接共役し て $\pi-\pi, n-\pi$ 共役によってカルボニ ウムイオンを安定化する機構が あ る。さらにここで問題にする垂直過 程での安定化として, 隣接 $\beta$-位 $\sigma$ 結合が電子供与的に非局化にたずさ わる $\sigma-\pi$ 共役が最近の話題である。 これは構造 (B) により示される。 その他電子供与性誘起効果 $(+I$ 効 果）もカルボニウムイオン安定化の 大きな要因としてあげられる。特 に, 有機金属化合物での $\sigma-\pi$ 共役で は金属一炭素 $\sigma$ 結合が関与するため, 電気的に陽性な金属原子による $+I$ 効果は重要な因子としていつも考慮 されるべきで， $\sigma-\pi$ 共役による安定

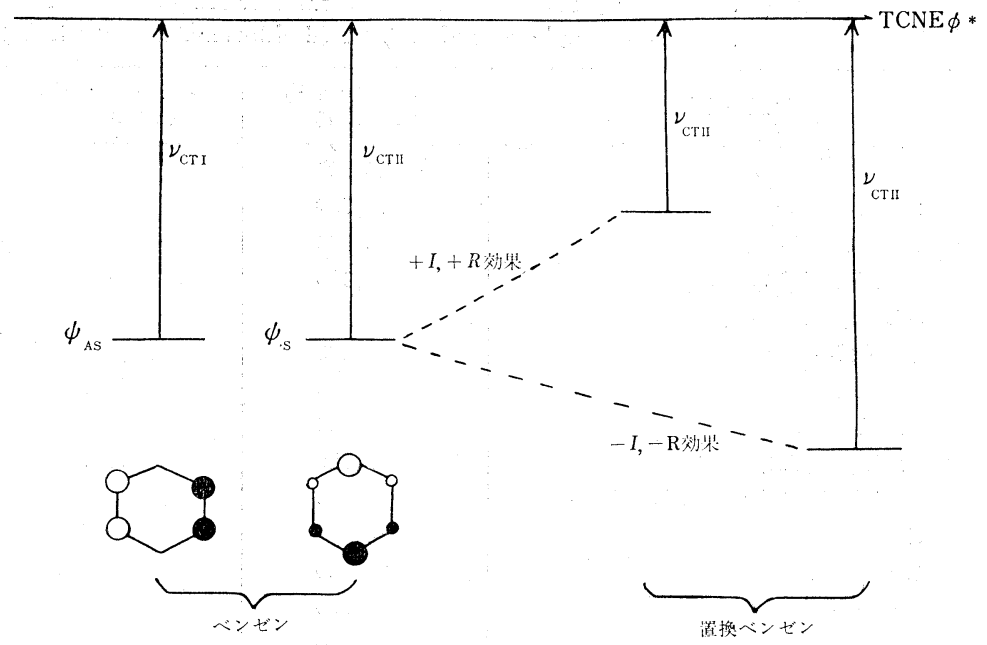

Fig. 1 Qualitative MO scheme of substituent effects influencing the charge transfer energies for substituted benzenes with TCNE.

化からこれを厳密に分離する心要がある。

化をもたらす置換基は電子供与性の $+I$ 効果や共役効果

また，加溶媒分解のような反応で生成するカルボニウ ムイオンの場合には開裂や脱離 (fragmentation) などを 伴うことが多く, 加速効果をもたらすことがある点に留 意しなければならない。

\section{4. $\boldsymbol{\sigma}-\boldsymbol{\pi}$ 共役の実証}

\section{1. 隣接基関与の分離 ${ }^{21 \mathrm{a}}$ 隣接基関与によるカル} ボニウムイオン安定化と $\sigma-\pi$ 共役による安定化を如何に 分離し実証することができるであろらか。Traylor らは 加溶媒分解では今まで余り明確にできなかった隣接基関 与による加速効果を，同じ置換基をもつベンゼン誘導体 のテトラシアノェチレン(以下 TCNE), ジクロロマレイ ン酸無水物 (DCMA) との電荷移動錯体形成反応を利用 して, 電荷移動 (CT) スペクトルを測定し，その CTエ ネルギー $\left(\nu_{\mathrm{CT}}\right)$ との比較から, 加溶媒 分解で同じよう に加速効果をもつ置換基が二つのグループに類別できる ことを見出した。電荷移動錯体形成反応は核の変動を伴 わない Franck-Condon 過程で起り，垂直過程で起る反 応とみなされる。したがって CT エネルギーに大きい変
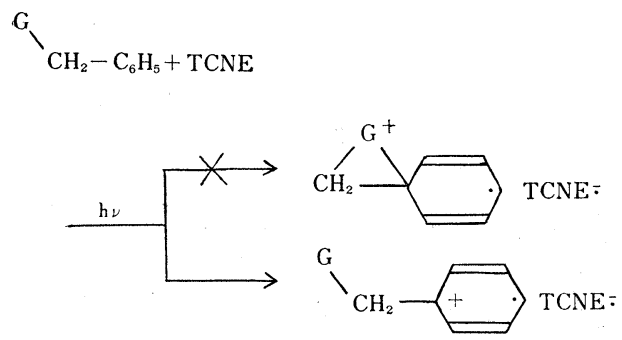
$(+R)$ をもつ置換基として，また，変化をもたらさない ものは $\mathrm{ND}_{\mathrm{I}}$ 隣接基関与基として整理されるのである。

なお CT エネルギーに及ぼすベンゼン上の置換基の 効果を簡単な模式図であらわすと図 1 のようになる。 結果は 表 1 に示すとおりで, 反応〔11]の速度を加速

$$
\mathrm{Y}-\mathrm{CR}_{2}-\mathrm{X} \longrightarrow \mathrm{YC}^{+} \mathrm{R}_{2}+\mathrm{X}^{-}
$$

するが，隣接基関与を起しえない置換基 $\mathrm{Y}=\mathrm{CH}_{3} \mathrm{O}-, \mathrm{CH}_{3}$ $\mathrm{CONH}-, \mathrm{CH}_{3^{-}}, \mathrm{C}_{6} \mathrm{H}_{5} \mathrm{O}-,, \mathrm{R}_{2} \mathrm{~N}$-基では同時にラジカルカ チオンの安定化をもたらし， $\nu \mathrm{CT}_{\mathrm{II}}$ を低波数側にシフト させる。一方， $\mathrm{ND}_{\mathrm{I}}$ によってカチオン生成を促進する 置換基 $\mathrm{Y}=\mathrm{CH}_{3} \mathrm{CONHCH}_{2^{-}}, \mathrm{CH}_{3} \mathrm{CH}_{2} \mathrm{OCH}_{2^{-}}, \mathrm{BrCH}_{2}$ な どでは $\nu \mathrm{CT}_{I I}$ は低下しない。このような簡単な手段によ って垂直安定化もしくは $+I$ 効果によって安定化をもた らす一群の置換基と, $\mathrm{ND}_{\mathrm{I}}$ による生成カチオンの安定 化をもたらす置換基の二つのグループに分類することが できる。今まで色分けが鮮明でなかった置換基 $\mathrm{Y}=\mathrm{RHg}$ $\mathrm{CH}_{2}, \mathrm{R}_{3} \mathrm{PbCH}_{2^{-}}$, シクロプロピル, 1-ビシクロ[2.1.1] ヘキシル基は，上のような相関関係から，垂直過程によ る電子供与性効果によってカチオン安定化に寄与するこ とが明らかとなった。

このように，炭素-金属 $\sigma$ 結合が隣接するカルボニウ ムイオンを安定化する現象は $\sigma-\pi$ 共役によるとして理解 できることは次の考察からも明らかである。正電荷を安 定化する置換基 Y の能力は直線自由 エネルギー 関係則 (Hammett 則) により整理されるであろう。加溶媒 分 解から得られた Hammett $\sigma_{\mathrm{Y}^{+}}$定数注電荷移動反応にお ける $\nu_{\mathrm{CT}}$ とよい直線性を示す（表 1 の $\sigma^{+}$(反応) と 
Table 1 Relationship between the charge transfer frequencies for substituted benzenes with TCNE (tetracyanoethylene) and DCMA (dichloromaleic anhydride) and $\sigma_{\mathrm{Y}}{ }^{+}$constants.

\begin{tabular}{|c|c|c|c|c|}
\hline Radical Y & $\begin{array}{c}\nu_{\mathrm{CT}}^{\max }\left(\mathrm{cm}^{-1}\right) \\
(\mathrm{TCNE})\end{array}$ & $\begin{array}{c}\nu_{\mathrm{cT} m} c_{a x}\left(m^{-1}\right) \\
(D C M A)\end{array}$ & $\sigma^{+}($Reaction $)$ & $\sigma^{+}(\mathrm{CT})$ \\
\hline $\mathrm{H}$ & 25,800 & & 0 & -0.03 \\
\hline $\mathrm{CH}_{3} \mathrm{O}-$ & 19,700 & 28,600 & -0.778 & -0.74 \\
\hline $\mathrm{CH}_{3} \mathrm{CONH}-$ & 20,800 & & -0.58 & -0.60 \\
\hline$\left(\mathrm{CH}_{3}\right)_{3} \mathrm{SiCH}_{2-}-$ & 20,100 & & -0.61 & -0.66 \\
\hline$\left(\mathrm{CH}_{3}\right)_{3} \mathrm{SnCH}_{2}-$ & & 26,700 & -0.76 & -0.9 \\
\hline $\mathrm{CH}_{3} \mathrm{CH}_{2}-$ & 24,200 & & -0.295 & -0.25 \\
\hline $\mathrm{Ph}_{3} \mathrm{PbCH}_{2-}$ & 16,300 & 25,840 & & -1.08 \\
\hline $\mathrm{Ph}_{8} \mathrm{PbCH}_{2} \mathrm{CH}_{2}-$ & 25,200 & & -0.3 & -0.22 \\
\hline $\mathrm{PhCH}_{2} \mathrm{HgCH}_{2-}$ & 15,780 & 24,940 & -1.11 & -1.12 \\
\hline $\mathrm{PhCH}\left(\mathrm{CH}_{3}\right) \mathrm{HgCH}\left(\mathrm{CH}_{3}\right) \mathrm{CH}_{2}-$ & 24,100 & & -0.3 & -0.25 \\
\hline $\mathrm{CH}_{3} \mathrm{CONH}_{2} \mathrm{CH}_{2}-$ & 24,400 & 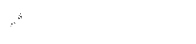 & & -0.19 \\
\hline $\mathrm{C}_{6} \mathrm{H}_{5} \mathrm{OCH}_{2-}$ & 25,300 & & & -0.10 \\
\hline $\mathrm{BrCH}_{2}-$ & 26,200 & & & 0.00 \\
\hline $\mathrm{CH}_{2} \mathrm{CO}_{2} \mathrm{Et}$ & 26,200 & & & 0.00 \\
\hline cyclo- $\mathrm{C}_{3} \mathrm{H}_{5}$ & 21,300 & & -0.54 & -0.53 \\
\hline $\mathrm{Me}_{2} \mathrm{~N}-$ & 19,200 & 21,230 & -1.7 & -0.75 \\
\hline $\mathrm{C}_{6} \mathrm{H}_{5} \mathrm{O}-$ & 20,200 & & -0.5 & -0.65 \\
\hline
\end{tabular}

$\sigma^{+}(\mathrm{CT})$ を比較せよ)。ここで注目すべきことは, $\mathrm{Ph}_{3}$ $\mathrm{PbCH}_{2}-\left(\sigma^{+}=-1.08\right)$ や $\mathrm{PhCH}_{2} \mathrm{HgCH}_{2}-\left(\sigma^{+}=1.12\right)$ で みられた大きい電子供与能力が,メチレン鎖を一つ増し た $\mathrm{Ph}_{3} \mathrm{PbCH}_{2} \mathrm{CH}_{2}-$, や $\mathrm{PhCH}_{2}\left(\mathrm{CH}_{3}\right) \mathrm{HgCH}\left(\mathrm{CH}_{3}\right) \mathrm{CH}_{2}-$

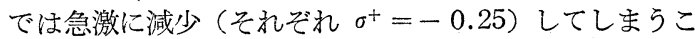
とである。 $+I$ 効果はメチレン鎖一つにつき通常 $1 / 2.8$ な゙つその効果が減少してしまうことが知られているの で，今もし $\nu_{\mathrm{CT}}$ の低波数シフトを全て $+I$ 効果による 電子供与能の中に押し込めてしまうと, $\mathrm{Ph}_{3} \mathrm{PbCH}_{2} \mathrm{CH}_{2}$ に対しては $\sigma^{+}=-0.55$ が予想される。したがって，実 際にみられた急激な CT エネルギ一の低下には金属の小 さな電気陰性度による $+I$ 効果では全く説明がつかな い。 $\sigma-\pi$ 共役がこの CT 遷移、ホルギーの低下に大き く寄与していることを示唆するものである。なお $I$ 効果 の分離に関しては次章に詳しく述べる。

金属一炭素 $\sigma$ 結合による $\sigma-\pi$ 共役は，今まで述べたよ うな $\mathrm{ND}_{\mathrm{I}}$ による隣接基安定化効果がないかわりに， $\beta$ 位にある $\sigma$ 結合が anchimeric assistance によって電子 を供給し，安定化をもたらす隣接基関与が同時に働くか もしれない。これは本来“共役”という意味からすると， $\sigma-\pi$ 共役と厳密に区別されるべきであろう。下に示すよ うな架橋が起るのであるが，このとき $\mathrm{G} の$ 移動の方向は 脱離基の動く方向と同じになる。(式〔12])。

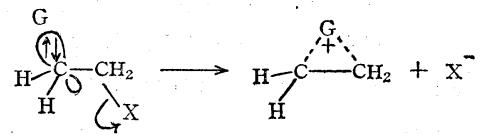

なお初期には，このような隣接 $\sigma$ 結合による安定化は， $\sigma-\pi$ 共役と区別されずに，超共役 ${ }^{10)} ， \sigma-\pi$ 非局在化 ${ }^{18)}$ あ るいは $\sigma$ 結合関与 $(\sigma \text {-bridging })^{23,24)}$ などと一緒にして 呼ばれていたものである。

カチオン安定化に際しての超共役をこのような架橋か ら分離する必要がある。反応論を用いた最初の明確な実 験がフェロセニルカルビニルカチオン系で行われ，この 際，次のよらな手段方用いられた。すなわち，フェニレ ン系を通してのカチオン安定化が， $\sigma-\pi$ 共役ならば可能 であろうという考えである ${ }^{21 \mathrm{~b}, \mathrm{c}) 。}$
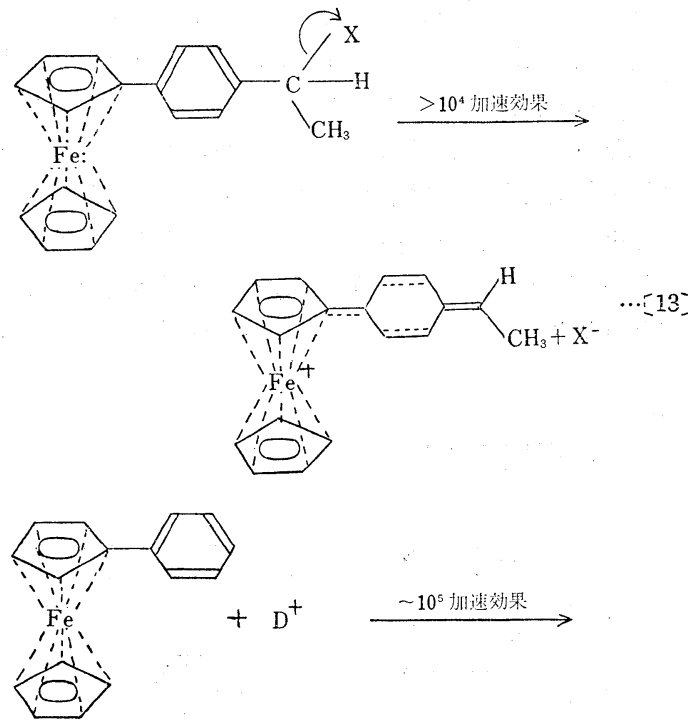


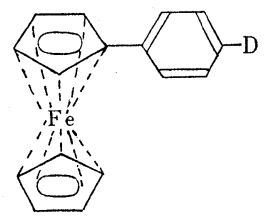

6） $\mathrm{C}_{\alpha}$ で正電荷を生成する 垂直過程（たとえば CT 反応，光電子スペクトルによるイオン化電圧の測定）と $\mathrm{C}_{\alpha}$ での $\mathrm{S}_{\mathrm{N}} 1$ 速度の比較 ${ }^{21 a)}$ 。

ここで，1）については既に述べた。2）では，分子内 であるいは分子外部からの求核試剤が同時に同一炭素上<smiles>[X]Cc1ccc(CSCC)cc1</smiles>

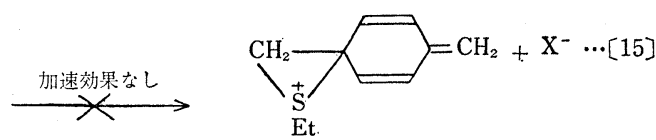

このように，隣接基関与 $\mathrm{ND}_{\mathrm{I}}$ によるカチオン安定化は フェニレン基が中間に插入されることによって伀達を妨 げられるが，（式〔15]），フェロセニル基が置換してい る場合にはなお大きな速度增加がみられた。この方法は その後, 数多くの他の金属-炭素結 合や歪みのかかった $\sigma$ 結合による $\sigma-\pi$ 共役を証明するための基本的な方法を 提供している ${ }^{21 \mathrm{a}, \mathrm{d}, \mathrm{h}, \mathrm{j}, 25,26)}$ 。

$\mathrm{C}_{6} \mathrm{H}_{5} \mathrm{CH}_{2} \mathrm{HgCH}_{2} \mathrm{C}_{6} \mathrm{H}_{5}$

$$
\underset{\sim 10^{8} \text { 加速効果 }}{\longrightarrow} \mathrm{C}_{6} \mathrm{H}_{5} \mathrm{CH}_{2} \mathrm{HgCH}_{2} \mathrm{C}_{6} \mathrm{H}_{4}-\mathrm{D}-p^{2.1 \mathrm{~d})} \ldots
$$

$$
p-\mathrm{R}_{3} \mathrm{MCH}_{2} \mathrm{C}_{6} \mathrm{H}_{4} \mathrm{SnMe}_{3}
$$

$$
\underset{\sim 10^{3} \text { 加速效果 }}{\longrightarrow} \mathrm{R}_{3} \mathrm{MCH}_{2} \mathrm{C}_{6} \mathrm{H}_{5}{ }^{25)}
$$

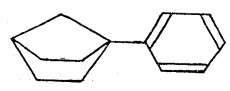

$$
+\mathrm{Bz} \mathrm{Cl} \underset{\text { 盎分加加速 }}{\stackrel{\mathrm{AlCl}_{3}}{\longrightarrow}}
$$

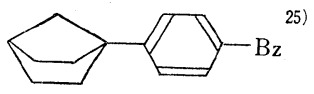

このような考察を進めてゆくと，一般にカチオン $(\mathrm{C})$ における $\sigma-\pi$ 共役と架橋による加速効果や, $\mathrm{ND}_{\mathrm{I}}$ 効果 $\mathrm{M} \backslash \mathrm{C}_{\beta}+\mathrm{C}^{\prime} \mathrm{R}^{\prime}$ を分離するためには次のような手段 $\mathrm{R}^{\prime}-\mathrm{C}_{\beta}-\mathrm{C}_{\alpha} \mathrm{R}^{\prime} \quad$ が適していると思われる。以下, 順 (C) を追って述べる。

1）先に触れたように， $\mathrm{C}_{\alpha}$ と $\mathrm{C}_{\beta}$ の間にフェニレン 基を挿入することによって加速效果が見出されるかどう か $^{21 \mathrm{~b}, \mathrm{c})}$ 。

2) $\mathrm{C}_{\alpha}$ 上での $\mathrm{S}_{\mathrm{N}} 1$ と $\mathrm{S}_{\mathrm{N}} 2$ 反応の速度の比較 ${ }^{21 i}$ 。

3） $\mathrm{C}_{\alpha}$ 上での置換基として $\mathrm{MR}_{2} \mathrm{C}_{\beta}$-基を多置換する ことにより観察される効果 ${ }^{211,27,28) 。}$

4）一方 $\mathrm{C}_{\beta}$ 上での置換基 $\mathrm{M}_{\mathrm{n}} \mathrm{R}_{3-\mathrm{n}} \mathrm{C}_{\beta}$-として $\mathrm{R} を \mathrm{M}$ で順次置換（ $\mathrm{n}$ 增大）したときにあらわれる効果 ${ }^{16,29)}$ 。

5） $\mathrm{C}_{\alpha}$ 上にカルボニル基があるとき $\nu_{\mathrm{C}=\mathrm{O}}$ 振縮振動 と $\mathrm{C}_{\alpha}$ での $\mathrm{S}_{\mathrm{N}} 1$ 速度の比較 ${ }^{21, \mathrm{c})}$ 。
$\left(\mathrm{C}_{\alpha}\right)$ で $\mathrm{S}_{\mathrm{N}} 2$ 置換を起すことができないため， $\sigma-\pi$ 共 役と $\mathrm{ND}_{\mathrm{I}}$ を区別できるであろう ((D) を参照)。

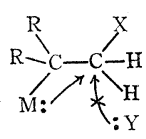

(D)

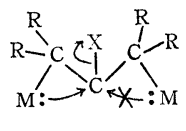

(E)
たとえばフェロセニルメチルクロリドの $\mathrm{S}_{\mathrm{N}} 2$ 反応が 非常に促進されるのは， $\sigma-\pi$ 共役によるものと結論され る ${ }^{21 i)}$ 。3）による方法でも同様で，二つの求核試薬が同 時に $\mathrm{C}_{\alpha}$ 上を攻撃することは立体効果によっても妨害さ れるので，起りえない（構造 (E) に示される)。しかし

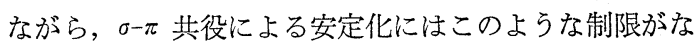
く, 垂直安定化基は他の共役基と同様，同時に作用を及 ぼすであろう(構造 (F) を参照))したがって式〔19】の反

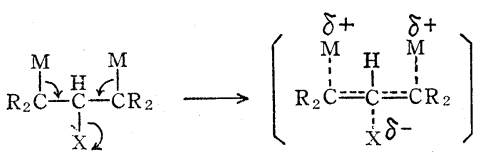

(F)

$$
\begin{aligned}
& \left(\mathrm{MCH}_{2}\right)_{\mathrm{n}}\left(\mathrm{CH}_{3}\right)_{3-\mathrm{n}} \mathrm{CX} \\
& \quad \longrightarrow\left(\mathrm{MCH}_{2}\right)_{\mathrm{n}}\left(\mathrm{CH}_{3}\right)_{3-\mathrm{n}} \mathrm{C}^{+}+\mathrm{X}^{-}
\end{aligned}
$$

応に対して,一つの基による加速効果を $\Delta$ とすると，もし 分子内求核性基（たとえば, $\mathrm{M}=\mathrm{NH}_{2}, \mathrm{OCH}_{3}$, 八ロゲン) の場合には，ほぼ置換基の倍数を掛けた $n(\Delta)$ だけ反応 を加速されるであらう。一方， $\sigma-\pi$ 共役基 ( $\mathrm{M}=\mathrm{RHg}$, $\mathrm{R}_{3} \mathrm{Sn}, \mathrm{R}_{3} \mathrm{Si}$, Cyclo- $\mathrm{C}_{3} \mathrm{H}_{5}$ など) に対してはおよそ $(\Delta)^{\mathrm{n}}$ の加速効果をもつはずである。実際，アリール基（M= $\mathrm{Ar})$ のときには $n(\Delta)$ だけ加速され ${ }^{30)}$ ，一方シクロプロ

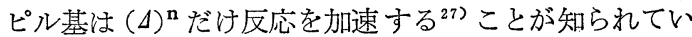
て，この仮定とよく一致する。ジフェロセニルケトンが フェロセニルメチルケトンよりも容易にプロトン化され ることはやはり $\sigma-\pi$ 共役によりよく説明できる。4）の 同一炭素 $\mathrm{C}_{\beta}$ 上にMが多置換した $(\mathrm{G})$ のとき， $\sigma-\pi$ 共役 よる安定化を考光ると，一般に加成性 には成立しない。つまり， $n(\Delta)$ でも $(\Delta)^{\mathbf{n}}$ でもない。これは $\sigma-\pi$ 共役には 後で詳しく述べるように, 強い geo-

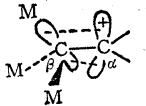

(G) metry の効果 (立体電子的効果) が支配的であるため, $\beta$-位の同一炭素上に多く金属などが 置換しても効果が 
相乗的に働かないためである。ただ $I$ 効果による安定化 が考慮される場合には加成性が成立するであるう。これ についての Eaborn の実験は興味深い(後述)。

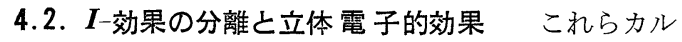
ボニウムイオンに隣接する金属-炭素 $\sigma$ 結合による安定 化効果注，多くの人によって，金属が陽性な元素である ためにI効果によるとして説明されていたことがある。 たとえば Bock らはベンジルメタル化合物の TCNE と の CT で $\nu_{\mathrm{CT}}$ が異常に低くなる原因を, 専ら $+I$ 効果 に押し込めて考察を加えてきた ${ }^{16)}$ 。しかし, $\mathrm{PhCH}_{2} \mathrm{Hg}$ $\mathrm{CH}_{2}$ 基などがラジカルカチオンを活性化する効果 $\left(\sigma^{+}=\right.$ -1.1) は $+I$ 効果だけに帰するのに沙少し大き過ぎる。 この有機金属化合物における $+I$ 効果を実験的に分離し た直接証明が，エチルカチオンのメチル基のように回転 対称をもつ置換基では起りえない立体電子的効果の存在 によってなされた*。

メチル基が $\pi$ 系に隣接する場合の超共役効果をみる （H）と，メチル基の $\mathrm{H}_{3}$ “擬原子” の生成により二つの $\pi$ 対称軌道と 1 つの $s$ 対称軌道が生じる。 $\mathrm{C}_{\beta}$ での混成 は $s p^{3}, s p^{0.25}, p, p$ となる。この二つの $p$ 軌道が $\mathrm{H}_{3}$ “擬原子” の二つの $\pi$ 型軌道と重なることになり, 二つ の超共役 $\sigma-\pi$ 系を作る》。しかしながら，この取扱いは 3 回軸対称基に対してのみ有効である。今問題となる金

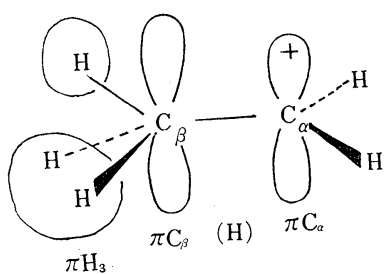

属一炭素 $\sigma$ 結合の場合には三つの $\sigma$ 結合のらち一つぞけ がより非局在化しやすいであろう。すなわち，M-C 結 合は $\mathrm{C}-\mathrm{H}$ 結合よりも小さいイオン化電圧をもつために $\mathrm{C}-\mathrm{H}$ 超共役は相対的に小さくなるため無視され，高揚 された M-C $\sigma$ 結合による $\sigma-\pi$ 共役のみが効果的にな る。 $\mathrm{HMO}$ で記述すると $\psi_{\sigma-\pi}=a \psi_{\mathrm{M}}+b \psi_{\mathrm{C}_{\beta}}+c \psi_{\mathrm{C}_{\alpha}}$ とな る。これは原子価結合法で表現すると $\psi_{\sigma-\pi}=a^{\prime} \psi \mathrm{C}_{\beta} \mathrm{M} \sigma$ bond $+b^{\prime} \psi \mathrm{C}_{\alpha}$ となり， $n-\pi$ 共役などと同様の表現であること がわかる。この $\sigma-\pi$ 共役を最大にす るには二つの軌道 $\sigma$ と $\pi$ の重なりが最

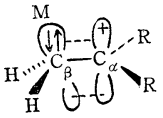

(I) 大になる必要がある。これには $p_{\pi}$ 軌道軸と $\mathrm{M}-\mathrm{C} \sigma$ 結 合のなす二面角 $\theta$ が小さくなり零に近づく程よいことは

*) $\mathrm{XCH}_{2} \mathrm{CH}_{2}$ 系 (カチオン, ラジカル, アニオン) とつ回䎐障壁の問題 に䵊して, 超共役に及ぼす置換基Xの效果が理論的に考察され， $a b$ inito 計算が二, 三の例で行われている4)。
明らかであろう。つまり立体電子的効果が支配的になる。 また， $\mathrm{C}_{\beta}$ 上の原子軌道係数が大であること(これは金 属が陽性になる程, 金属上の置換基が電子供与性である 程達成される。すでに気づいておられると思らが $\mathrm{M}-\mathrm{C}_{\beta}$ $\sigma$ 結合を図で表現するために $\mathrm{C}_{\beta}$ 上にのみの軌道を図示 し，M上での軌道表現を無視しているのは，このことを 誇張して表現しているためで, $\mathrm{C}_{\beta}$ 上での原子軌道倸数 が大きいことに対応する), さらには $\pi$ 軌道と $\sigma$ 軌道の エネルギー準位が近い程 $\sigma-\pi$ 共役が大きくなることは攝 動分子軌道法による考察からも明らかとなるであろら。

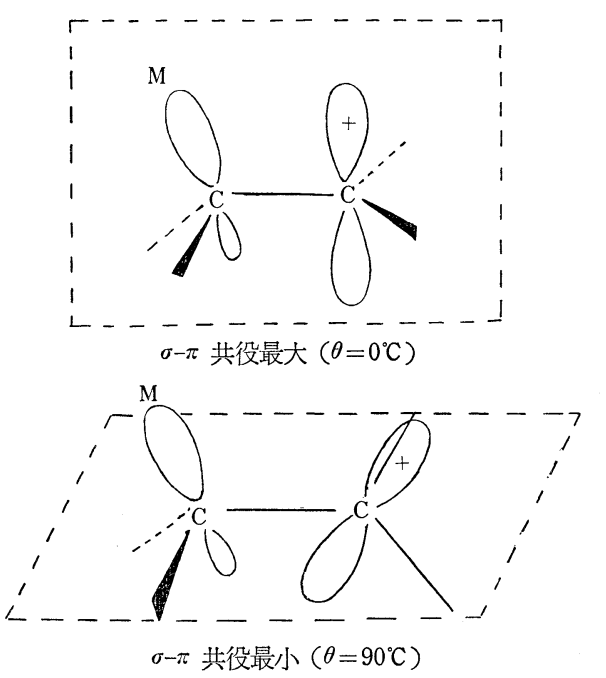

このように $+I$ 効果を一義的に $\sigma-\pi$ 共役から分離する ための最良の実験 は, 生成するカチオンの $\pi$ 軌道軸と $\mathrm{M}-\mathrm{C} \sigma$ 結合のなす二面角 $(\theta)$ と化学反応との相関関係

Table 2 Charge transfer frequencies for benzylmetal compounds with TCNE.

\begin{tabular}{l|r}
\hline \multicolumn{1}{c|}{ Compounds } & $2 \mathrm{CT}_{\mathrm{II}}\left(\mathrm{cm}^{-1}\right)$ \\
\hline $\mathrm{PhCH}_{3}(1)$ & 24,300 \\
$\mathrm{PhCH}_{2} \mathrm{SnPh}_{3}(2)$ & 18,800 \\
$\mathrm{PhCH}_{2} \mathrm{HgC}_{6} \mathrm{H}_{11}(3)$ & 15,000 \\
\hline
\end{tabular}


を調べればよい。垂直過程として以前に述べたと同様, 置換ベンゼンの TCNE との CT 錯体形成反応を選ん で, $\nu_{\mathrm{CT}}$ と $\theta$ の関係が調べられた ${ }^{21 \mathrm{j})}$ 。(表 2)

自由回転しらるベンジルメタル化合物 (2), (3) では CT 吸収の長波長シフトは著しい。一方, 金属一炭素 $\sigma$ 結合 がほぼベンゼン $\pi$ 軌道節平面内に固定された geometry をもつ化合物 (5)，(7)，（8）では予想通り $\nu \mathrm{CT}_{I I}$ は それぞれ詨照化合物に比較して変化がない。かくして $+I$ 効果がベンジルメタル化合物の CT エネルギーに対 して支配的に働くとの考えは否定される。同様の実験は Pitt ら ${ }^{30)}$ によりなされた。また，紫外スペクトルでも

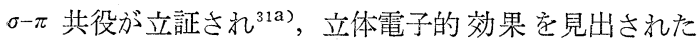
$31 \mathrm{~b}, \mathrm{c})$ 。

\section{5. 光電子スペクトルを用いたイオン化 電圧の測定と $\sigma-\pi$ 共役}

このような $\sigma-\pi$ 共役の実証をより確実にするために， また, 直接検出するためには真空紫外光電子 $(\mathrm{PE})$ スペ クトルがよい。PE スペクトルによる中性分子のイオン 化電圧 (IP) の測定は, 各種ラジカルカチオンを生成す る垂直過程での一種の反応とるなされ，そのエネルギー

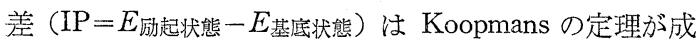
立する限りにおいて分子軌道準位を直接反映している。 したがって CT スペクトルでのように最高被占軌道に 関する情報だけでなく,より内部の軌道準位や電子状態 を厳密に知ることができる。二つの軌道間相互作用によ って分裂する新たな軌道の両方共を直 接観测できるの で, $\sigma-\pi$ 共役や他の分子内での軌道間相互作用の直接証 明に都合よい ${ }^{32)}$ 。

有機化学者が光電子スペクトロメーターを手にする時 期が遅れたので $\sigma-\pi$ 共役の実証にはそれ程役立たなかっ たが，PEによるIP の測定から最近では $\sigma-\pi$ 共役が実 証されている。例を一つあげよう。 $\mathrm{Me}_{3} \mathrm{Sn}\left(\mathrm{CH}_{2}\right)_{\mathrm{n}} \mathrm{CH}=$ $\mathrm{CH}_{2}$ の $\mathrm{PE}$ をとると，nの变化により $\pi$ 軌道準位が大 きく変化することが観察された ${ }^{33}$ （表 3)。明らかに， $\mathrm{n}=1$, すなわちアリルトリメチルスズでは $\pi_{\text {HоMо }}$ が $\mathrm{Sn}-\mathrm{C} \sigma$ 結合との相互作用により不安定化し $\mathrm{IP}_{1}(8.70$

Table 3 Vertical ionization potentials $(\mathrm{eV})$ of $\mathrm{Me}_{3} \mathrm{Sn}\left(\mathrm{CH}_{2}\right)_{\mathrm{n}} \mathrm{CH}=\mathrm{CH}_{2}$.

\begin{tabular}{l|c|c|c|c}
\hline \multicolumn{1}{c|}{ Campoud } & $\mathrm{IP}_{1}$ & $\mathrm{IP}_{2}$ & $\mathrm{IP}_{3}$ & $\mathrm{IP}_{4}$ \\
\hline $\mathrm{Me}_{4} \mathrm{Sn}$ & 9.75 & $\sim 13$ & & \\
$\mathrm{Me}_{3} \mathrm{SnCH}=\mathrm{CH}_{2}$ & 9.7 & 10.5 & & \\
$\mathrm{Me}_{3} \mathrm{SnCH} \mathrm{CH}_{2} \mathrm{CH}_{2}$ & 8.70 & 9.76 & 10.87 & \\
$\mathrm{Me}_{3} \mathrm{Sn}\left(\mathrm{CH}_{2}\right)_{2} \mathrm{CH}=\mathrm{CH}_{2}$ & 9.71 & 11.74 & & \\
$\mathrm{Me}_{3} \mathrm{Sn}\left(\mathrm{CH}_{2}\right)_{3} \mathrm{CH}=\mathrm{CH}_{2}$ & 9.72 & 10.40 & & \\
\hline
\end{tabular}

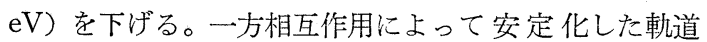
が $\mathrm{IP}_{3}(10.87 \mathrm{eV})$ としてあらわれる。相互作用パラメ ーター（重なり積分）として $|\beta|=1.3 \mathrm{eV}$ をらる。一

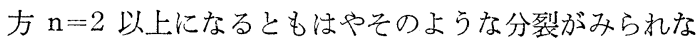
い。このような $\sigma-\pi$ 共役の直接証明は他に一般に $\mathrm{CH}_{2}=$ $\mathrm{CHCH}_{2} \mathrm{X}\left(\mathrm{X}=\right.$ 金属 ${ }^{34 \mathrm{a})}$, 八ロゲン ${ }^{34 \mathrm{~b})}$, 硫黄 $\left.{ }^{34 \mathrm{c}}\right), \mathrm{Ph}$ $\mathrm{CH}_{2} \mathrm{MR}_{3}{ }^{34 \mathrm{a})}$ などにおいて行われた。ポリシラン ${ }^{35)}$ ，シ クロプロピルカルビニルトリメチルスズ33b)，1，1-およ

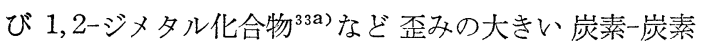
$\sigma$ 結合や，金属一炭素 $\sigma$ 結合間での $\sigma-\sigma$ 相互作用が非常 に大きいことも，PE による IP の測定から直接証明さ れている $[(\mathrm{J}) \sim(\mathrm{M})] 。$

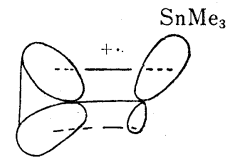

(J)

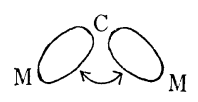

(L)

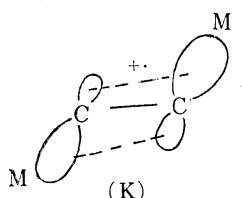

$(\mathrm{K})$

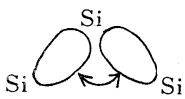

( $\mathrm{M})$

\section{6. $\boldsymbol{\sigma}-\boldsymbol{\pi}$ 共役と化学反忘性}

今まで $\sigma-\pi$ 共役の概念と他の効果によるカチオン安 定化の分離の化学的，物理的な手段による方法について 詳しく述べた。以下に $\sigma-\pi$ 共役が反応性を支配してい る代表的な若干の興味ある反応をあげる。

\section{1. トリチルカチオンによる $\beta$-ハイドライド引き抜} きによる生成カチオンの安定性と立体化学 アセトニ トリルのような非プロトン性, 非求核性溶媒中でトリチ ルカチオン $\left(\mathrm{Ph}_{3} \mathrm{C}^{+}\right)$活泩化された $\mathrm{C}-\mathrm{H}$ 結合からハイ ドライドを引き抜いてカルボニウムイオンを与える。基 質として $\mathrm{Et}_{4} \mathrm{M}(\mathrm{Si}, \mathrm{Ge}, \mathrm{Sn}, \mathrm{Pb})$ を用いたとき $\beta$-位水 素が撰択的に引き抜かれ，この反応の速度定数が $\mathrm{Ph}$ $\mathrm{CH}_{2} \mathrm{MR}_{\mathrm{n}}$ の TCNE との CT エネルギーとよい相関を

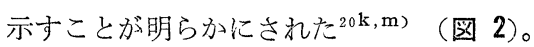

$$
\begin{aligned}
& \stackrel{\mathrm{R}_{\mathrm{n}} \mathrm{M} \backslash \underset{\mathrm{CH}_{2}-\mathrm{CH}_{2}}{\mathrm{H}}+\mathrm{Ph}_{3} \mathrm{C}^{+}}{\stackrel{\mathrm{h}}{\mathrm{CH}_{3} \mathrm{CN}} \stackrel{\mathrm{Rn}_{\mathrm{n}}{ }^{+}}{\longrightarrow} \stackrel{\mathrm{CH}_{2}=\mathrm{CH}_{2}+\mathrm{Ph}_{3} \mathrm{CH}}{\longrightarrow} \longrightarrow \mathrm{R}_{\mathrm{n}} \mathrm{M}^{+}+\mathrm{CH}_{2}=\mathrm{CH}_{2}}
\end{aligned}
$$

この反応では金属と anti-periplanar な水素が引き拔か 
れることが示される。すなわちcis-および trans-4-t-ブ チルシクロヘキシルトリメチルスズと $\mathrm{Ph}_{3} \mathrm{C}^{+} \mathrm{BF}_{4}$ - の反 応速度を比較すると, axial- $\mathrm{SnMe}_{3}$ 基の方がより速く, anti 脱離を優先する ${ }^{20 \mathrm{k})}$ 。

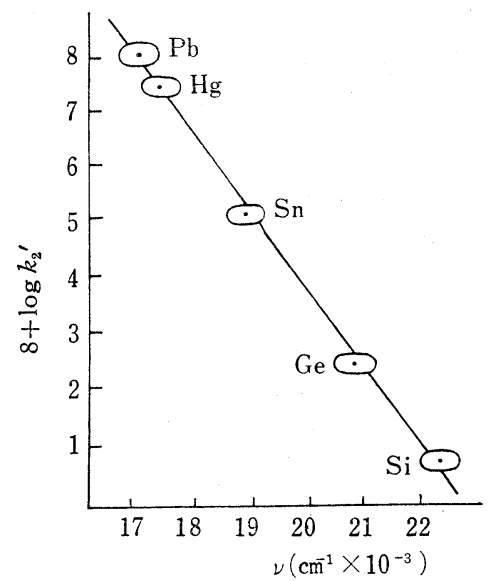

Fig. 2 Plot of $\log k_{2}$ for reaction of $\mathrm{Ph}_{3} \mathrm{C}^{+}$with $\mathrm{Et}_{\mathrm{n}} \mathrm{M}$ against charge-transfer frequencies for $\mathrm{PhCH}_{2} \mathrm{MPh}$ with tetracyanoethylene.

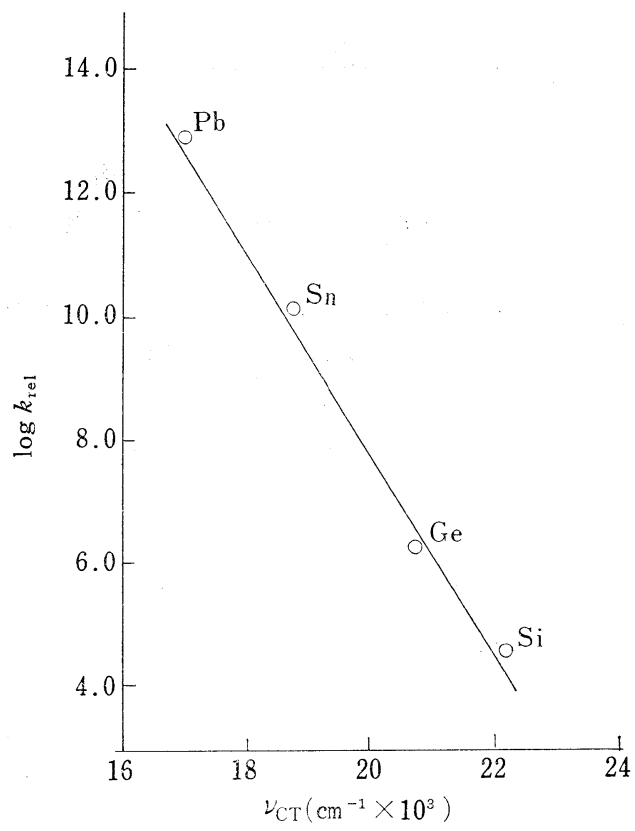

Fig. 3 Plot of $k_{\text {rel }}$ from protodemetalation reactions against charge-transfer frequencies for $\mathrm{Ph}$ $\mathrm{CH}_{2} \mathrm{MPh}_{5}$.

次に示す化合物の反応の立体化学の検討は, これをさ らに確実なものにする ${ }^{36)}$ 。
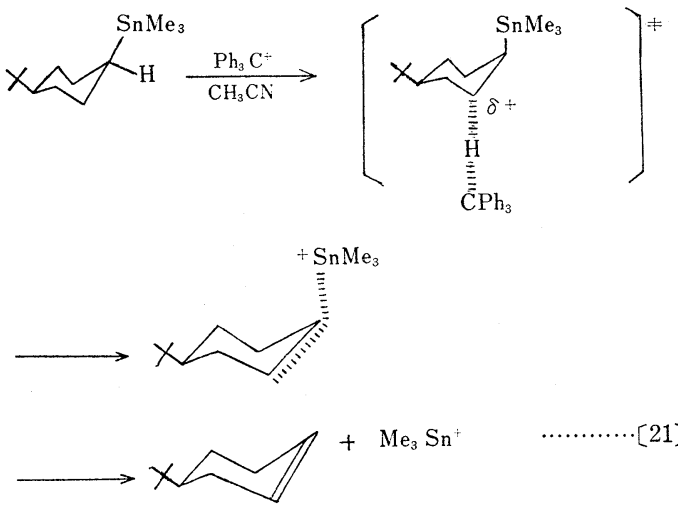

この反応が〔22]式のように anti 方向で起るならば, 生成するオレフィンは Dが $\mathrm{Ph}_{3} \mathrm{C}^{+}$で引き抜かれたとき には trans 体が，Hが引き抜かれると cis 体を与え，し かもDを残した cis-ブテン-2 を与えるはずである。実

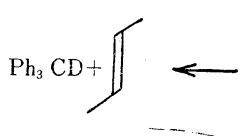

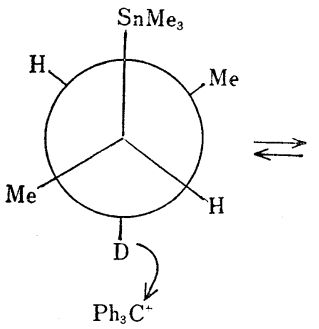<smiles>[2H]/C(C)=C/C=[Pb]</smiles>

際に得られた化合物は 1 個のDが置換された cis-ブテン とD-置換されていない trans-ブテンー2 であった。この 反応は注ぼ完全に anti 方向からの引き技きと脱離を起 している強力な証拠となる。

\section{2. 親電子試薬による脱メタル芳香核置換反庇 ${ }^{37}(1$} プソ置換反応）一般に $\mathrm{Ar}$-金属結合はプロトン， $\mathrm{NO}_{2}{ }^{+}$, ハロゲンのような親電子試導によって非常に容易 に切断をらける。簡単化のためこの反応の中間体が Eaborn らにより指摘されたよらに Wheland 型の $\sigma$ 錯 体 (N) とすると, それでは $\mathrm{M}-\mathrm{C} \sigma$ 結合が空の $p_{\pi}$ 軌 道と eclipse に近い構造, すなわち $\sigma-\pi$ 共役が働くため にかなり都合のよい構造をとるよらになる。この反応は $\mathrm{M}=\mathrm{C} \ll \mathrm{Si}<\mathrm{Ge} \ll \mathrm{Sn} \ll \mathrm{Pb}$ の順に速くなり，一般にいわれ 


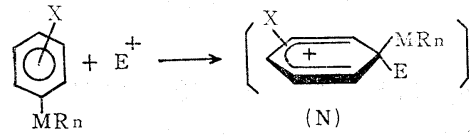

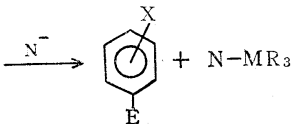

る $\sigma-\pi$ 共役による電子供与能力と一致していることは心゙ ンジルメタル化合物-TCNE の $\nu_{\mathrm{CT}}$ とのよい直線性か らも示される ${ }^{38)}$ (図 3)。この反応で $p$-位に $\left(\mathrm{Me}_{3} \mathrm{Si}\right)_{\mathbf{n}}$ $\mathrm{CH}_{3-\mathrm{n}}$-基を導入した 置換基効果の検討を行うと， $\mathrm{n} の$ 増大により必ずしも速度が増加しないことから， $\mathrm{Me}_{3} \mathrm{Si}$ $\mathrm{CH}_{2}$ 基の電子供与能は $+I$ 効果によるとしては説明で きないことが表 4の結果に示される ${ }^{39) 。 ~}$

Table 4 Relative rates of protodesilylation of $\mathrm{X}-\mathrm{C}_{6} \mathrm{H}_{4} \mathrm{SiMe}_{3}$ in $\mathrm{HClO}_{4}-\mathrm{MeOH}-\mathrm{H}_{2} \mathrm{O}$.

\begin{tabular}{l|c|l|r}
\hline \multicolumn{1}{c|}{$\mathrm{X}$} & $k_{\text {rel }}$ & \multicolumn{1}{c|}{$\mathrm{X}$} & $k_{\text {rel }}$ \\
\hline $\mathrm{H}$ & 1.00 & $p-\mathrm{CH}_{3}$ & 21 \\
$m-\mathrm{CH}_{3}$ & 2.43 & $p-\mathrm{CH}_{2} \mathrm{SiMe}_{3}$ & 280 \\
$m-\mathrm{CH}_{2} \mathrm{SiMe}_{3}$ & 6.48 & $p-\mathrm{CH}\left(\mathrm{SiMe}_{3}\right)_{2}$ & 670 \\
$m-\mathrm{CH}\left(\mathrm{SiMe}_{3}\right)_{2}$ & 8.42 & $p-\mathrm{C}\left(\mathrm{SiMe}_{3}\right)_{3}$ & 200 \\
$m-\mathrm{C}\left(\mathrm{SiMe}_{3}\right)_{3}$ & 3.46 & & \\
\hline
\end{tabular}

一つの $\mathrm{SiMe}_{3}$ の置換に対しては大きい速度増加がみ られるが，さらに $\mathrm{SiMe}_{3}$ が同一炭素上に置換してもそ の効果は小さい。これは4 章に述べた 4) の効果の検討 に相当する。これら二つの結果とも，プロトン付加によ って生成する中間体が付加基および置換基の金属-炭素 $\sigma$ 結合により共役的に安定化されているとすることがで きる。

$p-\left(\mathrm{Me}_{3} \mathrm{Si}\right)_{\mathrm{n}} \mathrm{CH}_{3-\mathrm{n}} \mathrm{C}_{6} \mathrm{H}_{4} \mathrm{CO}_{2} \mathrm{H}$ の $50 \%$ 水 $-\mathrm{EtOH}\left(25^{\circ} \mathrm{C}\right)$ での酸解離定数および $p-\left(\mathrm{Me}_{3} \mathrm{Si}\right)_{\mathrm{n}} \mathrm{CH}_{3-\mathrm{n}} \mathrm{C}_{6} \mathrm{H}_{4} \mathrm{CMe}_{2} \mathrm{Cl}$ の含水アセトン中での加溶媒分解速度加ら求めた置換基 の $\sigma^{+}$定数の検討からも, シリル基によるカチオン安定 化は $+I$ 効果による説明は不可能 ${ }^{29 c)}$ で, $\sigma-\pi$ 共役がこ のような有機金属化合物の反応性を支配していることを 示す。

6.3. フェロセニルカルビニル系の加溶媒分解亡生成 物の立体化学 1-フェロセニルエチルアセタートの加 水分解によるカルボニウムイオン生成の速い速度と生成 物での立体保持の反応は，このような $\sigma-\pi$ 共役による説 明が妥当であると考えられる一つの典型的な反応であ る $^{40)}$ 。

アセタートがイオン化する際, その遷移状態において （O）に示すように geometry が変化せずに $\sigma-\pi$ 共役に よってカルボニウムイオンの安定化が起り, 速度を加速

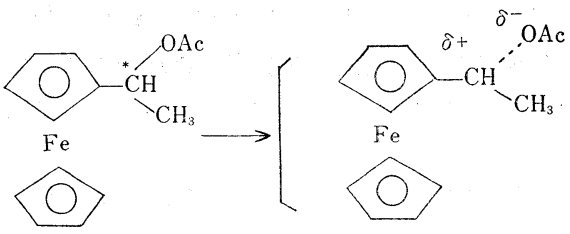

OAc

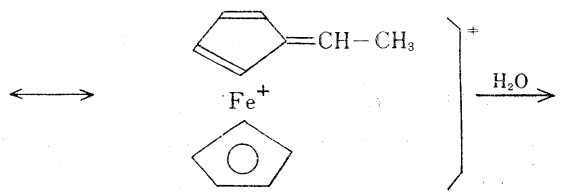

(O)

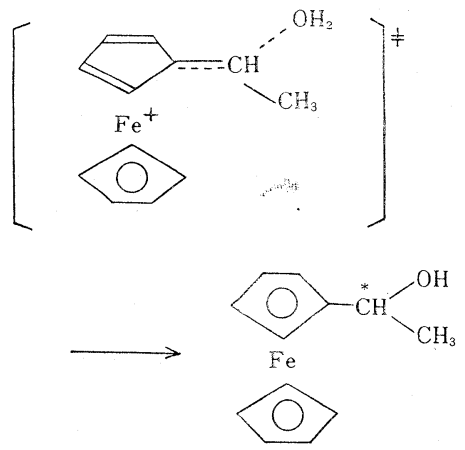

する。一方, 微視的可逆性原理から, 求核試斉である水 は，そのカチオンとの反応において同じ geometry を保 ちつつ反応する。

\subsection{C-H $\boldsymbol{\sigma}$ 結合へのジクロロカルベン插入反応}

Seyferth らは ${ }^{41)} \mathrm{PhHgCCl}_{2} \mathrm{Br}$ の熱分解により生成す る遊離のジクロロカルベンは有機金属化合物と反忍して $\beta-\mathrm{C}-\mathrm{H}$ 結合への捙入生成物を与えることを見出した。 金属の $\beta$-位 $\mathrm{CH} \sigma$ 結合の異常な反忘は何に基因するも のであるか興味深い。

$\mathrm{R}_{3} \mathrm{MCH}_{2} \mathrm{CH}_{2} \mathrm{R}^{\prime}+\mathrm{PhHgCCl}_{2} \mathrm{Br}$

$$
\longrightarrow \underset{\mathrm{R}_{3} \mathrm{MCH}_{2} \mathrm{CHR}_{1}^{\prime}+\mathrm{PhHgBr}}{\mathrm{CHCl}_{2}}
$$

金属の違いによる反忘性の順住 $\mathrm{Si} \ll \mathrm{Sn}<\mathrm{Hg}$ で, プロト ン化脱金属芳香核 置換反応や, $\mathrm{Ph}_{3} \mathrm{C}^{+}$によるハイドラ イド引き抜き反応の反応性順序と一致している。この反 応は立体化学保持で進行し, ベンジル位 C-H 結合やフ エニルシランの $\mathrm{Si}-\mathrm{H}$ 結合への挿入の置換基効果などの 動力学研究の結果, Hammett プロットは負の值を示し, 同位体効果 $k_{\mathrm{H}} / k_{\mathrm{D}}$ がかなり大きい值をもつ。これらは $: \mathrm{CCl}_{2}$ が親電子性のカルベンであり反応の遷移状態の構 造治源系に近く， $\beta$-位の有機 金 属基が遷移状態に発 現する部分正電荷を電子的に安定化しうるためと考えら れる ${ }^{42 a, b)}$ 。完全に正電荷が生成してくる反応でないに 
もかかわらず，金属による大きい反応性の差は $\beta$-位金 属による $+I$ 効果とするには大き過ぎ, 遷移状態におけ る $\sigma-\pi$ 共役が重要な因子であることを示唆する。彼ら

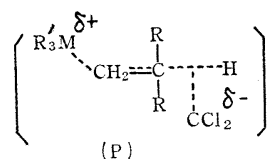

(P)

はこの反応に対して構造 $(\mathrm{P})$ を提案している。

われわれは 2-シラビシクロ〔2.2.1〕へプタンを合成 し， $\mathrm{CCl}_{2}$ 挿入反応を検討した。6-位，しかもexo-C$\mathrm{H} \sigma$ 結合に対して regio-および stereoselective に : $\mathrm{CCl}_{2}$ が挿入した生成物を与える ${ }^{43)}$ 。<smiles>[R20]C1C2CCC1C2</smiles><smiles>c1ccccc1</smiles>

(95\% 以上exo 体)
4- $\mathrm{CH}$, (三級)，6- $\mathrm{CH}_{2}, 7-\mathrm{CH}_{2}$ と 3 種類の $\beta-\mathrm{CH}$ 結合 があるにもかかわらず挿入が 6 位にしか起らぬこと, し かも Si-C $\sigma$ 結合が $\mathrm{C}_{6}-\mathrm{H}_{\text {exo }} \sigma$ 結合とほぼ anti-planar な関係にあることなどは, 遷移状態にあらわれる部分正 電荷弲 $\sigma-\pi$ 共役により安定化されているとして解釈され る。特にこの系では，1）金属 (ケイ素)-炭素 $\sigma$ 結合, 2) ビシクロ系であるため高度の歪みが $\mathrm{SiC} \sigma$ 結合に大 きくしわ寄せされているといら二重に高揚された $\sigma$ 結合 が存在することは，この反応に対する立体因子を評価す る方法がまだ不十分であるにもかかわらず，2-ノルボル ニル系における大きい exo/endo 速度比に対する数多く の論争 ${ }^{44)}$ とも関連して興味深い結果であろう。

\section{5. ケトンのヒドリド還元における $\sigma-\pi$ 共役}

遷移金属錯体では $\pi$-錯体化されたカルボニウムイオン の安定化はよく知られている。ところでクラスタ一錯体 であるアシルメチルトリコバルトノナカルボニルの $\mathrm{Et}_{3}$ $\mathrm{SiH}-\mathrm{CF}_{3} \mathrm{CO}_{2} \mathrm{H}-\mathrm{THF}$ 系でのヒドリド還元 ${ }^{45,46 \mathrm{a})}$ が非常 に容易に進行することが見出された。

これは途中に生成するカルボニウムイオンが遷移金属

$$
\begin{aligned}
& (\mathrm{CO})_{9} \mathrm{Co}_{3} \mathrm{CCR} \stackrel{\mathrm{O}}{\stackrel{\mathrm{Et}_{3} \mathrm{SiH}}{\longrightarrow}}\left(\mathrm{CO}_{9} \mathrm{Co}_{3} \mathrm{CCHR}\right. \\
& \begin{array}{r}
\stackrel{\mathrm{CF}_{3} \mathrm{CO}_{2} \mathrm{H}}{\longrightarrow}(\mathrm{CO})_{3} \\
\stackrel{\mathrm{Et}_{3} \mathrm{SiH}}{\longrightarrow}(\mathrm{CO})_{9} \mathrm{Co}_{3} \mathrm{CCH}_{2} \mathrm{R}
\end{array}
\end{aligned}
$$

一炭素 $\sigma$ 結合による $\sigma-\pi$ 共役によって安定化されること が見出された珍らしい例である ${ }^{46 \mathrm{~b}) 。 ~}$

6.6. アリルメタル化合物 を用いた 炭素-炭素結合生 成反応 $\quad \sigma-\pi$ 共役が考えられるアリルシランなど一般 に $\mathrm{CH}_{2}=\mathrm{CHCH}_{2} \mathrm{MR}_{3}(\mathrm{M}=\mathrm{Si}, \mathrm{Ge}, \mathrm{Sn})$ などで示される化合 物では, エノールエーテルやエナミンと同様に $\pi$-結合 が求核性を示すであろら。実際 TCNE のような親電子 性のオレフィンとの間で炭素-炭素結合を作りうること が示されている ${ }^{47)}$ 。<smiles>CC(C#N)C(C#N)C(C)C#N</smiles>

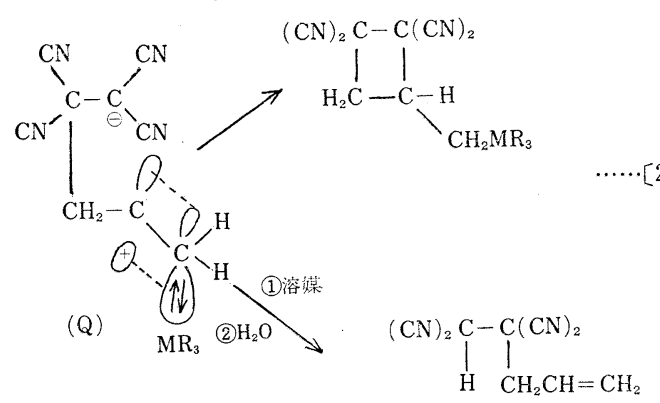

明らかに中間体 (Q) における $\sigma-\pi$ 共役安定化が反応の 駆動力で, 二段階を経てシクロ付加体を与えるかもしく は，中間体 $(\mathrm{Q})$ は溶媒と反応して $\mathrm{R}_{3} \mathrm{M}^{+}$が脱離したオ レフィンを与えるようになる。

この $\pi$ 結合の高い求核性を利用してアリルシランを 用いた有機合成が最近見出された。その一つは酸ハロゲ ン化物を Lewis 酸触媒下アリルシランと反応すると対 応する $\beta, \gamma$ 一不飽和ケトンが収率よく生成する ${ }^{48)}$ 。

$\mathrm{Me}_{3} \mathrm{SiCH}_{2} \mathrm{CH}=\mathrm{CH}_{2}+\mathrm{RCOCl}$

$$
\stackrel{\text { Lewis酸 }}{\longrightarrow} \mathrm{CH}_{2}=\mathrm{CHCH}_{2} \mathrm{COR}+\mathrm{Me}_{3} \mathrm{SiCl}
$$

$$
\mathrm{R}=\mathrm{Ph}, \mathrm{Me}, \mathrm{Et} \text { (収率 70 80\%) }
$$

一方, アルデヒドやケトンのような一般のカルボニル化 合物も $\mathrm{AlCl}_{3}, \mathrm{TiCl}_{4}, \mathrm{SnCl}_{4}, \mathrm{BF}_{3} \cdot \mathrm{Et}_{2} \mathrm{O}$ のような Lewis 酸でカルボニル基の分極(活性化)を促すことによって， 新しい炭素一炭素結合を生成することがわかった。式 $\mathrm{Me}_{3} \mathrm{SiCH}_{2} \mathrm{CH}=\mathrm{CH}_{2}+\mathrm{R}^{\prime} \mathrm{COR}^{\prime \prime}$

$$
\underset{\mathrm{CH}_{2} \mathrm{Cl}_{2}}{\stackrel{\text { Lewis酸 }}{\mathrm{H}_{2} \mathrm{O}}} \longrightarrow \mathrm{CH}_{2}=\mathrm{CHCH}_{2} \mathrm{CR}_{1} \mathrm{R}^{\prime \prime}
$$

[30]の反応の最大の特色核来の Grignard 試薬やリ 
チウム試薬によっては不可能であった反応の regiospecifity が完全に保たれることである。式〔31]，〔32〕こ $\mathrm{R}$

$$
\begin{aligned}
& \mathrm{Me}_{3} \mathrm{SiCHCH}=\mathrm{CH}_{2}+\mathrm{R}^{\prime} \mathrm{COR}^{\prime \prime}
\end{aligned}
$$

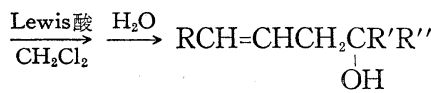

$\mathrm{Me}_{3} \mathrm{SiCH}_{2} \mathrm{CH}=\mathrm{CHR}+\mathrm{R}^{\prime} \mathrm{COR}^{\prime \prime}$

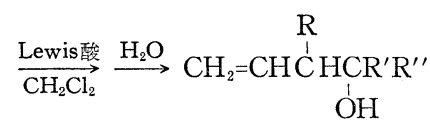

のように新しい炭素-炭素結合はケイ素から $ケ$-位のアリ ル基の炭素上で起る。

6.7. 高歪み化合物での $\boldsymbol{\sigma}-\boldsymbol{\pi}$ 共役 ${ }^{21 \mathrm{~h})}$ 高揚された $\sigma-\pi$ 共役の例として今まで，分極した金属-炭素 $\sigma$ の結 合を取りあげてきたが，もう一つの代表例として主題と は関係はないがシクロプロパンのように歪みの大きい $\sigma$ 結合孔興味あるので簡単に触孔る。

シクロプロパンの環外 $\sigma$ 結合は $s$ 性が大きいことか ら考えると, シクロプロピル基はむしろ電子吸引性基と して働いてもよいように思わ礼るが，奇妙なことに隣接 炭素陽イオンの安定化効果は非常に大きく, 加溶媒分解 速度は異常に速い。しかもフェニル基による安定化より も大きい。この大きい安定化効果は架橋によるとも考元 られるが，シクロプロピルベンゼンの TCNE との CT エネルギーも同時に低くし， $\nu_{\mathrm{CT}}$ が加溶媒分解速度とよ い相関を示している。つまり垂直安定化，すなわち $\sigma-\pi$ 共

Table 5 Charge transfer frequencies for $\mathrm{R}-\mathrm{C}_{6} \mathrm{H}_{5}$ with TCNE compared with relative rates of the solvolysis of $\mathrm{RCH}_{2} \mathrm{X}$.

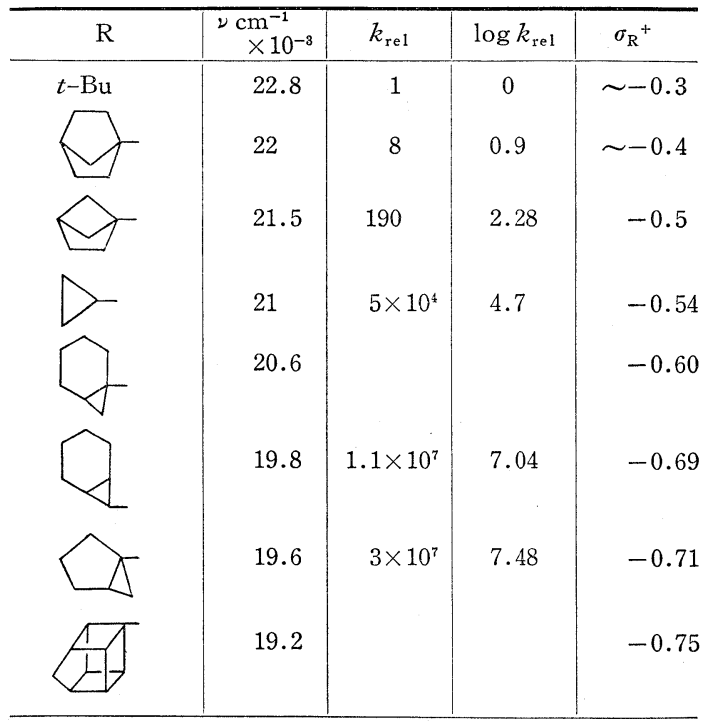

役によりシクロプロピル基は隣接炭素陽イオンの安定化 をむたらしている。(表 5) より高度の歪みのかかった ホモキュビル基, 1-ビシクロ[3.1.0]ヘキシル基ではさ らに速度が速くなる（それぞれ $\sigma_{\mathrm{R}}{ }^{+}=-0.71,-0.75$ ) こともこの結論が正当であることを明白にしている。

\section{7. ラジカル, 中性分子, アニオンに おける $\boldsymbol{\sigma}-\boldsymbol{\pi}$ 共役}

$\sigma-\pi$ 共役はカチオンに対しては大きい安定化効果をも つことが明らかになった。MO 記述によると $\sigma$ 軌道と $\pi$ 軌道の相互作用によってできる二つの軌道のうち安定化 軌道に 2 電子を収容できるので全エネルギーが低下す る。一方ラジカルでは不安定化軌道に一つの電子が入る ためその安定化効果は大幅に減じられ, 中性分子, アニ オンでは逆に全エネルギーは不安定化する。ラジカル反 応に招いては $\sigma-\pi$ 共役が反応性の増大や，コンホメー ションの優先性に影響を与えることが見出され，これは 最近の興味ある話題である。

われわれはアルケニルシランに対する $\mathrm{BrCCl}_{3}$ のラジ カル付加の相対速度を調べたとき，アリルシランでの10 倍に近い加速効果を見出している。ただケイ素の場合, ラジカル $p_{\pi}$ 電子がケイ素 $3 d$ 空軌道に対して供与的に 働く $p-d$ ホモ共役による安定化効果が無視できない50)。 特に生成するラジカル $p_{\pi}$ 軌道の節平面近くに geometry が固定されたシラシクロブタンと $t$-ブトキシラジカル の反応でラジカル (R) が非常に生成しやすいことはそ の原因の一部として $(\mathrm{R})$ に抢ける立体障害の減少にも 帰せられるが，興味深い(1)。esr で検出されるラジカル 種は完全にこれ一種類だけであること， $\beta-\mathrm{CH}$ 結合の水 素引き抜きの相対反応性が少くともべンジル位水素以上 の反応性を示すこと，またマレイン酸ジメチルとは $\beta$ 位で付加した 1: 1 付加物のみを収率よく与えることな どの結果からえられる結論である。

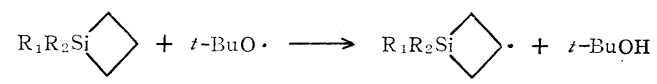

(R)

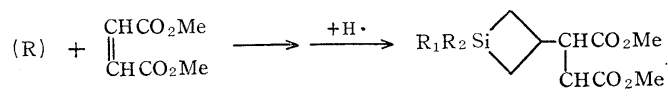

この系では $\sigma-\pi$ 共役による安定化を期待しにくい。一 方，プロトン化脱メタル反応でみられたように $\mathrm{Ar}$-金属 結合は金属ラジカルによってipso 位置換を容易にうけ る52)。やはり金属に対して $\beta$-位ラジカルが生成するの ルあるが，中間体 $(\mathrm{S})^{53)}$ が 2 つの金属により $p-d$ 木モ 
$\mathrm{RnMC}_{6} \mathrm{H}_{5}+\mathrm{R}_{3} \mathrm{M}^{\prime} \longrightarrow \rightleftharpoons{ }_{\mathrm{M}^{\prime} \mathrm{R}_{3}}^{\mathrm{MRn}}$

(S)

$\longrightarrow \mathrm{R}_{8} \mathrm{M}^{\prime} \mathrm{C}_{6} \mathrm{H}_{5}+\mathrm{RnM} \cdots \cdots \cdot[35]$

共役もしくは 2 つ金属-炭素 $\sigma$ 結合による $\sigma-\pi$ 共役に より安定化効果をうけるのか，興味がつきない。 esr を用いたコンホメーションに対する $\beta$-位金属置撸 基の効果も, $\sigma-\pi$ ，もしくは $p-d$ ホモ共役により議論さ れているがまだ完全に解決をみていない年皇。詳しくは吉 良，桜井の総説をみられたい、占。

\section{8. 結語}

$\sigma-\pi$ 共役による主としてカルボニウムイオンの安定化 を反応例をあげながら重点的に解説してきた。最後に $\sigma-\pi$ 共役に及ぼす因子が，今までの理諭的，実験的な集 積の結果から Traylor によって要約されているので紹 介しておこう。隌にカチオンができるような反応，た とえば $\mathrm{R}_{3} \mathrm{ABR}_{2}{ }^{\prime} \mathrm{CR}_{2}{ }^{\prime \prime} \mathrm{X}$ の加溶媒分解を例として主要な 部分を 図 4 に示す。

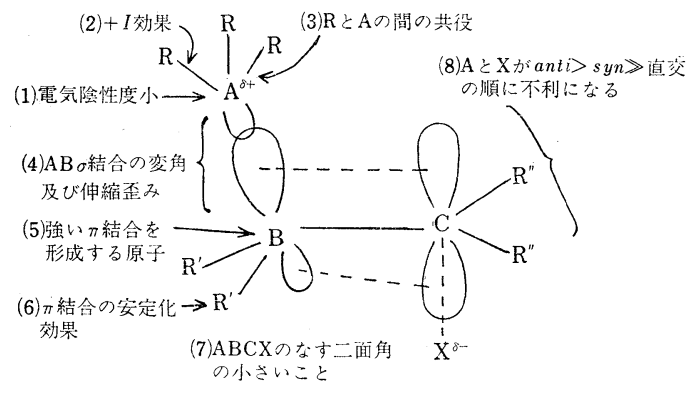

Fig. 4

$\sigma-\pi$ 共役がカチオンの安定化に齐してどのように働く か，この図は簡潔で明快な解答を与える。ただ加溶媒分 解のときは $\sigma-\pi$ 共役は主要なカチオン安定化因子となり らるが， $\sigma-\pi$ 共役は結合角や結合距離にあまり依存しな いので遷移状態が架橋構造を含みうること注注意すべき である。

最後に有益なご助言をして頂いた Teddy G. Traylor 教授 (Univ. of Calif., San Diego) に深甚なる謝意を 表する次第である。

（昭和 50 年 8 月 4 日受理）

\section{文献}

1) G.E. Coates, M.L.H. Green, P. Powell, K. Wade, "Principles of Organometallic Chemistry" Methuen, London (1968)

2) A.W.P. Jarvie, Organometal. Chem, Rev. A 6 153 (1970)

2a）熊田誠，山本 経二，玉尾皓平，“有機金属の反
応” 化学同人, 化学増刊 54 (1970) p. 3 に簡単 に記述されている。

3) C.G. Pitt, J. Organometal. Chem. 6149 (1973)

4) R. Hoffmann, L. Radom, J.A. Pople, P.v.R. Schleyer, W.J. Hehre, L. Salem, J. Amer. Chem. Soc. 946221 (1972) とその引用文献

5) 吉良満夫，桜井英樹，化学の領域 29121 (1975); H. Sakurai, M. Kira, J. Amer. Chem. Soc. 96 791 (1974)

6) J.W. Baker, W.S. Nathan, J. Chem. Soc. 1935 1844

7a) R.S. Mulliken, J. Chem. Phys, 7339 (1939)

b) R.S. Mulliken, Tetrahedron 668 (1959)

c) R.S. Mulliken, ibid. 5251 (1959)

8) M.J.S. Dewar, H.N. Schmeising, ibid. 1196 (1960)

9) M.J.S. Dewar, "Hyperconjugation" Ronald Press, New York (1962)

10) J.D. Roberts, R.H. Mazur, J. Amer. Chem. Soc. 732509 (1951)

11) G.W. Wheland, "Resonance in Organic Chemistry" John Wiley \& Sons, New York, 1955, p. 442

12) P.D. Bartlett, "Nonclassical Ions" Benjamin, New York, 1955

13) C.A. Grob, F. Ostermeyer, Helv. Chim. Acta 451119 (1962)

14) W.M. Schubert, D.F. Gurka, J. Amer. Chem. Soc. 911443 (1969)

15) R.W. Bott, C. Eaborn, D.R.M. Walton, J. Organometal. Chem. 2154 (1964) およびその 引用文献

16) H. Bock, H. Alt, J. Amer. Chem. Soc. 92 1569 (1970); Idem, Angew. Chem., Int. Ed. Engl. 6943 (1967)

17) H.C. Brown, J. Chem. Soc. 19561248

18) A.N. Nesmeyanov, I.F. Lutsenko, Dokl. Akad. Nauk SSSR 59707 (1948)

19) Yu. G. Bundel, N.D. Antonova, O.A. Reutov, ibid. 1661103 (1966)

20) C. Eaborn, J. Chem. Soc. 19564858

21a) W. Hanstein, H.J. Berwin, T.G. Traylor, J. Amer. Chem. Soc. 92829 (1970)

b) T.G. Traylor, J.C. Ware, Tetrahedron Lett. 19651295

c) Idem, J. Amer. Chem. Soc. 892304 (1967)

d) W. Hanstein, T.G. Traylor, Tetrahedron Lett. 19674451

e) J.A. Mongravite, T.G. Traylor, ibid. 1967 4457

f) T.T. Tidwell, T.G. Traylor, J. Org. Chem. 332614 (1968)

g) T.G. Traylor, Accounts Chem. Res. 2152 (1969)

h) N.A. Clinton, R.S. Brown, T.G. Traylor, J. 
Amer. Chem. Soc. 925228 (1970)

i) T.T. Tidwell, T.G. Traylor, ibid. 883442 (1966)

j) W. Hanstein, H.J. Berwin, T.G. Traylor, ibid. 927476 (1970)

k) T.G. Traylor, H.J. Berwin, J. Jerkunica, M.L. Hall, Pure Appl. Chem. 30599 (1972)

1) T.G. Traylor, H.J. Berwin, N.A. Clinton, R.S. Brown, J. Amer. Chem. Soc. 935715 (1971)

m) J.M. Jerkunica, T.G. Traylor, ibid. 936278 (1971)

22) S. Winstein, Quart. Rev. 23141 (1969)

23) S. Winstein, D. Trifan, J. Amer. Chem. Chem. Soc. 74 1147; 1152 (1952)

24）Winstein らは架橋や超共役が連続して変化する 現象の三つの極限状態として捉えている。S. Winstein, B.K. Morse, E. Gruwald, K.C. Schreiber, J. Corse, ibid. 741113 (1952)

25) C. Eaborn, J. Chem. Soc. 19564858

26) F.R. Jensen, B.F. Smart, J. Amer. Chem. Soc. 915686 (1969)

27) H.M. Hart, P.A. Law, ibid. 861457 (1964)

28) C.J. Lancelot, P.v.R. Schleyer, ibid. 914091 (1969)

29a) A.R. Bassingdale, C. Eaborn, D.R.M. Walton, J.C. Young, J. Organometal. Chem. 2049 (1969)

b) A.R. Bassingdale, C. Eaborn, D.R.M. Walton, ibid. 2191 (1970)

c) M.A. Cook, C. Eaborn, D.R.M. Walton, ibid. 24293 (1970)

30) C.G. Pitt, ibid. 23 C 35 (1970)

31a) H. Sakurai, M. Kira, M. Ochiai, Chem. Lett. 197287

b) H. Sakurai, H. Tasaka, M. Kira, J. Amer. Chem. Soc. 949285 (1972)

c) V.A. Petrukov, V.F. Mironov, P.P. Shorygin, Izv. Acad. Nauk SSSR, Ser Khim. 122203 (1964)

32）細見彰，化学の領域 29553 (1975) およびその 引用文献

33a) A. Hosomi, T.G. Traylor, J. Amer. Chem. Soc. 973682 (1975)

b) R.S. Brown, D.F. Eaton, A. Hosomi, T.G. Traylor, J.M. Wright, J. Organometal. Chem. 66249 (1974)

34a) A. Schweig, U. Weidner, G. Manuel, ibid. 67 C 4 (1974) およびその引用文献

b) H. Schmidt, A. Schweig, Angew. Chem., Int. Ed. Engl. 12307 (1973)

c) W. Schäfer, A. Schweig, Chem. Commun. 1972824
35) H. Bock, W. Ensslin, Angew. Chem., Int. Ed. Eugl. 10404 (1971)

36) S.J. Hannon, Ph.D. Dissertation, Univ. of Calif., San Diego (1975)

37a) C. Eaborn, R.W. Bott, "Organometallic Compounds of the Group IV Elements" A.G. MacDiarmid, Ed., Marcel Dekker, Vol. 1. 1968

b) R.W. Bott, C. Eaborn, P.M. Greasley, J. Chem. Soc. 19604804 およびその引用文献

38) H.J. Berwin, Chem. Commun. 1972237

39) C. Eaborn, ibid. 19721225

40) E.H. Hill, J.H. Richard, J. Amer. Chem. Soc. 833849 (1961)

41) D. Seyferth, S.S. Washburne, C.J. Attridge, K. Yamamoto, ibid. 924405 (1970)

42a) D. Seyferth, H.-M. Shih, J. Dubac,P. Mazerdles, B. Serres, J. Organometal. Chem. 5039 (1973)

b) D. Seyferth, Y.M. Cheng, J. Amer. Chem. Soc. 956763 (1973)

43）細見彰，桜井英樹，第 23 回有機金属討論会（東 京 1975 要旨集 p. 11

44) H.C. Brown, Accounts Chem. Res. 6377 (1973)

45）ヒドロシランによるヒドリド還元の機構は別の 総説に詳しい。桜井英樹, 化学の領域 24671 (1970); 細見彰，ibid. 29528 (1975)

46a) D. Seyferth, G.H. Williams, J.E. Hallgren, J. Amer. Chem. Soc. 95266 (1973)

b) G. Deleris, J. Dunogues, R. Calas, J. Organometal. Chem. 9343 (1975)

47) G. Hartman, T.G. Traylor, Tetrahedron Lett. 1975939

48) M.R. Dubois, J. Dunogues, R. Calas, J. Organometal. Chem. 9731 (1975)

49a）細見彰, 桜井英樹, 第 34 回日化会春季年会, 神 奈川, 1976

b) D. Seyferth, M.O. Nestle, A.T. Wehman, J. Amer. Chem. Soc. 977417 (1975) およびその 引用文献

50) H. Sakurai, A. Hosomi, M. Kumada, J. Org. Chem. 341764 (1969)

51）細見彰，野末幾男，桜井英樹，第31回日化会秋季 年会, 仙台, 1974, 要旨集 $3 \mathrm{G} 06$; 第32回日化会 春季年会，東京，1975，要旨集 III-2A37

52）桜井英樹, 細見彰, 野末幾男, 第20回有機金属化 合物討論会, 京都, 1972, 要旨集 p. 108

53) 反応中間体 (S) が 3,5-ジ-t-ブチル-1-トリメチ ルシリルベンゼンと $\mathrm{R}_{3} \mathrm{M}^{\prime}$ ・の反応で esrにより 直接検出された。H. Sakurai, I. Nozue, A. Hosomi, Chem. Lett. 1976129

54) M.C.R. Symons, Tetrahedron Lett. 1975793 およびその引用文献 